\title{
Flexural Retrofitting of RC Beams Using Extra Rebars and U-Wraps
}

\author{
Abilash George Varughese ${ }^{1}$, T. Manikandan² \\ ${ }^{1}$ P.G. Student, Department of Civil Engineering, PSNA College of Engineering and Technology, Dindigul, Tamil Nadu, India \\ ${ }^{2}$ Assistant Professor, Department of Civil Engineering, PSNA College of Engineering and Technology, Dindigul, Tamil Nadu, India
}

\begin{abstract}
More recently, near-surface mounted (NSM) FRP reinforcement has attracted an increasing amount of research as well as practical application. In this experimental study, the effectiveness of NSM bars as a means of restoring or upgrading the flexural capacity of RC beams is investigated. A total of nine beam specimens of grade M20, length $1 \mathrm{~m}$ and cross-section of (150mmx200mm) were casted and tested by two point load method. Out of these, beams were retrofitted with steel rods and GFRP rods using Near Surface Mounted (NSM) technique, externally bonded with FRP U-wraps after applying 75\% of the ultimate load. A comparative study was made with the test results.
\end{abstract}

Keywords: Fiber Reinforced Polymer (FRP), Near Surface Mounted (NSM), energy absorption capacity, ductility, debonding.

\section{Introduction}

Over the last few years, external bonding/wrapping of fibrereinforced polymer (FRP) composites has become a very popular method for the strengthening of deficient reinforced concrete (RC) structures. Consequently, extensive research has been carried out on this strengthening technique. FRP composites are formed by embedding continuous fibres in a resin matrix which binds the fibres together. Common fibres include carbon, glass, and aramid fibres while common resins are epoxy, polyester, and vinyl ester resins. The most widely used FRP composites are glass fibre reinforced polymer (GFRP) composites, carbon fibre-reinforced polymer (CFRP) composites, and aramid fibre-reinforced polymer (AFRP) composites

Table 1: Qualitative Comparison between E-Glass, Aramid and Carbon Fibres

\begin{tabular}{|c|c|c|c|}
\hline Criterion & $\begin{array}{c}\text { E-Glass } \\
\text { Fibers }\end{array}$ & $\begin{array}{c}\text { Carbon } \\
\text { Fibers }\end{array}$ & $\begin{array}{c}\text { Aramid } \\
\text { Fibers }\end{array}$ \\
\hline Compressive Strength & Very Good & Very Good & Inadequate \\
\hline Tensile Strength & Good & Very Good & Very Good \\
\hline Young's Modulus & Adequate & Very Good & Good \\
\hline Long-Term Behaviour & Adequate & Very Good & Good \\
\hline Fatigue Behaviour & Adequate & Excellent & Good \\
\hline Bulk Density & Adequate & Good & Excellent \\
\hline Alkaline Resistance & Inadequate & Very good & Good \\
\hline Price & Very good & Adequate & Adequate \\
\hline
\end{tabular}

\section{A. Objectives}

The objectives of this study includes

- To investigate the improvement in flexural strength of reinforced concrete beams using Near Surface Mounted (NSM) technique and Externally Bonded Reinforcing (EBR) technique.

- To evaluate the mode of failure of beams before and after the strengthening of beams.

\section{B. Methodology}

1) Externally Bonded Reinforcing (EBR) technique:

Fibre Reinforced Polymer can be effectively used for upgrading and strengthening concrete structures. The
FRP sheets are generally applied externally on the surface of the structural element to be strengthened using an adhesive. This is called Externally Bonded Reinforcing (EBR) technique. Epoxy resin is used as adhesive.

2) Near Surface Mounted (NSM) technique:

Near Surface Mounted (NSM) strengthening technique is based on the concept of embedding FRP bars into grooves made on the concrete cover of the elements to be strengthened. Application of near surface mounted reinforcement consists of the following working steps.

- Grooves are cut in the concrete cover on the element to be strengthened.

- Further preparation of the groove consists of cleaning the surface from dust and loose particles using vacuum or compressed air. Then the groove is filled halfway with adhesive.

- Afterwards the FRP bar or strip is inserted and pressed to let the adhesive flow around the FRP. High strength epoxy resin grout is used for groove filling.

\section{Experimental Investigations}

\section{A. Materials}

The cement used is OPC of 53 Grade. The fine aggregate used is fine sand, which confirms to zone II of IS: $383-$ 1970. The coarse aggregate used confirms to IS: $383-$ 1970.GFRP sheet is used for flexural strengthening of reinforced concrete beams in this study. Nitowrap EP (GF) is a $1.3 \mathrm{~mm}$ thick glass fibre composite wrapping system, used in this study. Its mechanical properties include density of $1800 \mathrm{~kg} / \mathrm{m} 3$ and tensile strength of $1600 \mathrm{MPa}$. The $10 \mathrm{~mm}$ dia GFRP bars had density of $1990 \mathrm{~kg} / \mathrm{m} 3$ and modulus of elasticity of $40 \mathrm{GPa}$ whereas the $10 \mathrm{~mm}$ dia steel bars had modulus of elasticity of 200GPa. Abrick epoxy resin wasused to bond the GFRP sheet to the concrete. The resin was mixed with the hardener in the ratio of 100:18. The GFRP bars as well as steel bars of $10 \mathrm{~mm}$ diameter each were used for flexural strengthening of reinforced concrete beams in this study. High strength epoxy resin grout is used for groove filling in NSM method. 


\section{International Journal of Science and Research (IJSR) \\ ISSN (Online): 2319-7064}

Index Copernicus Value (2013): 6.14 | Impact Factor (2015): 6.391

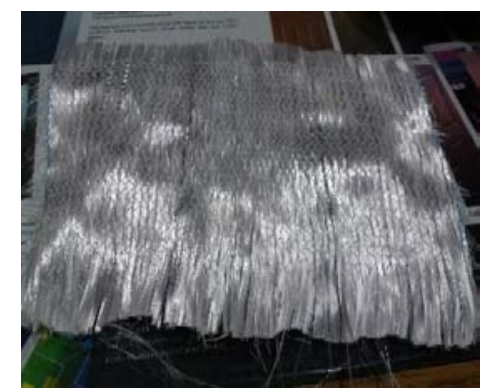

Figure 1: GFRP sheet

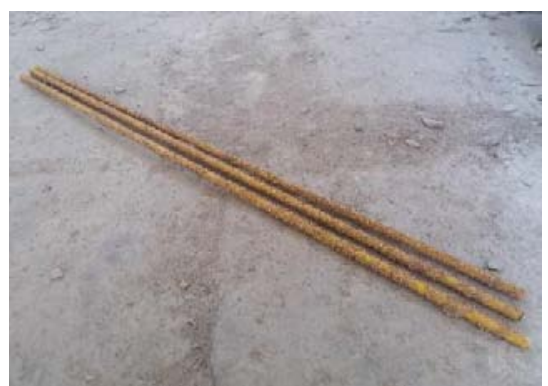

Figure 2: Sand coated GFRP bars

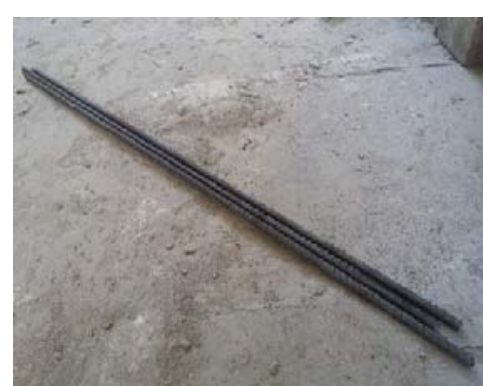

Figure 3: Steel deformed bars

\section{B. Beam Specimen Details}

A total of 9 beams of length $1 \mathrm{~m}$ and cross-section of $(150 \mathrm{mmx} 200 \mathrm{~mm})$ were tested in this study. For each type, three specimens were prepared. The specimen details are given in Fig4.and Table 2.
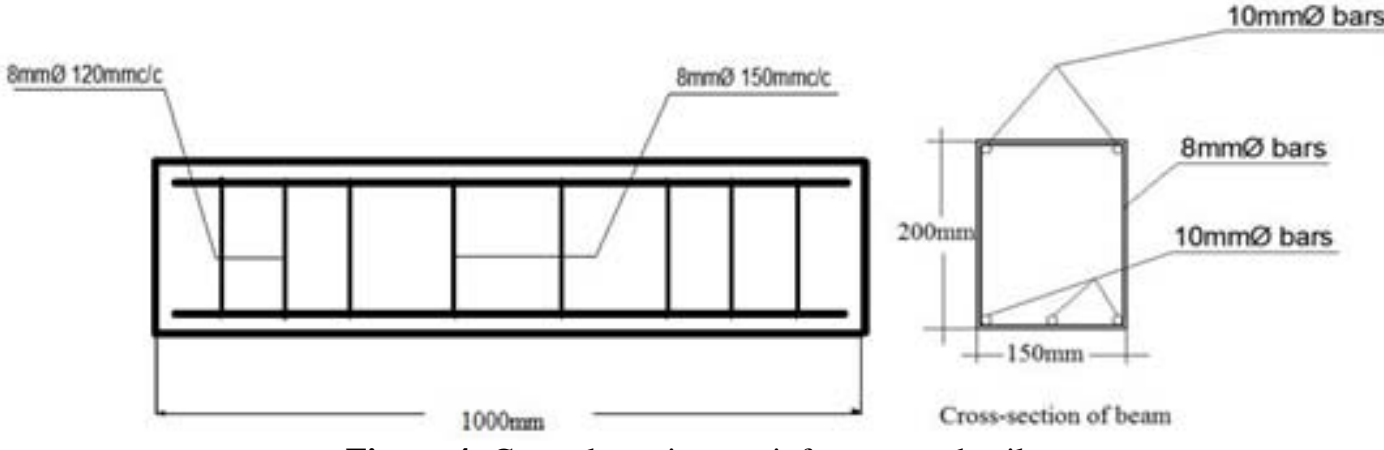

Figure 4: Control specimen reinforcement details

The bottom tension reinforcement consisted of 3 nos. of deformed steel bars of nominal diameter $10 \mathrm{~mm}$ running along the full length of the beams. The top compression reinforcement consisted of 2 nos. deformed steel bars of nominal diameter $10 \mathrm{~mm}$. The beams were designed to avoid compression failure due to concrete crushing and shear failure before failure of the strengthening system. Shear reinforcement consisted of double-legged steel stirrups deformed steel bar of nominal diameter $8 \mathrm{~mm}$ uniformly spaced at $120 \mathrm{~mm}$ centre to centre at both ends and $150 \mathrm{~mm}$ centre to centre at the midspan.

Table 2: Specimen details

\begin{tabular}{|c|c|c|}
\hline $\begin{array}{c}\text { No: of } \\
\text { Specimens }\end{array}$ & $\begin{array}{c}\text { Specimen } \\
\text { designation }\end{array}$ & FRP strengthening system \\
\hline 3 & CB & No strengthening \\
\hline 3 & FRG & $\begin{array}{c}\text { 2 NSM GFRP reinforcing bars } \\
\text { with GFRP U-wrap }\end{array}$ \\
\hline 3 & FRS & $\begin{array}{c}\text { 2 NSM Steel reinforcing bars } \\
\text { with GFRP U-wrap }\end{array}$ \\
\hline
\end{tabular}

\section{Flexural Strengthening Schemes}

All specimens with one and two grooves (15x15 mm each) along the beam were made dust and debris free before the application of the repair epoxy-bonding agent (Abrick) which was applied in two layers. Fig 5 gives an illustration of the grove size and position in the specimen.The second layer was applied after insertion of the required steel or GFRP bars. After application of epoxy, it was levelled with the adjacent concrete level and left for curing. In NSM method, GFRP strip is reinforced on the surface of the beam. In the first type two $10 \mathrm{~mm}$ dia GFRP bars are reinforced on the tensile face of the beam. In second type two $10 \mathrm{~mm}$ dia steel strip are reinforced. Details of NSM method are shown in Fig 5, 6 and 7.
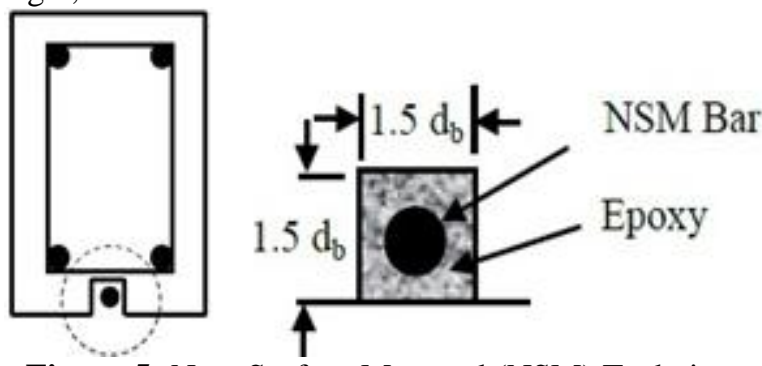

Figure 5: Near Surface Mounted (NSM) Technique 


\section{International Journal of Science and Research (IJSR) \\ ISSN (Online): 2319-7064}

Index Copernicus Value (2013): 6.14 | Impact Factor (2015): 6.391
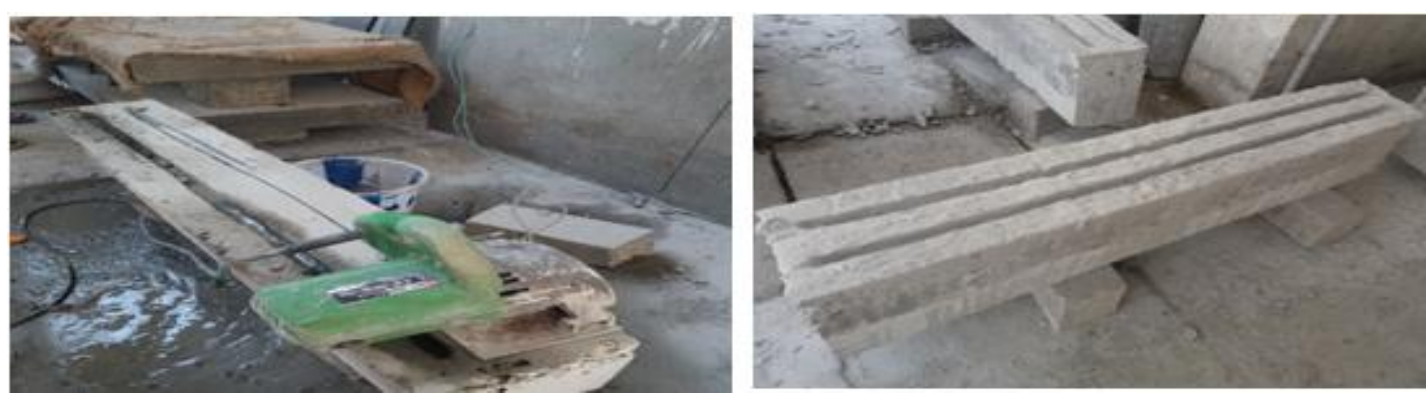

Figure 6: Grooves made on the bottom surface of the specimen

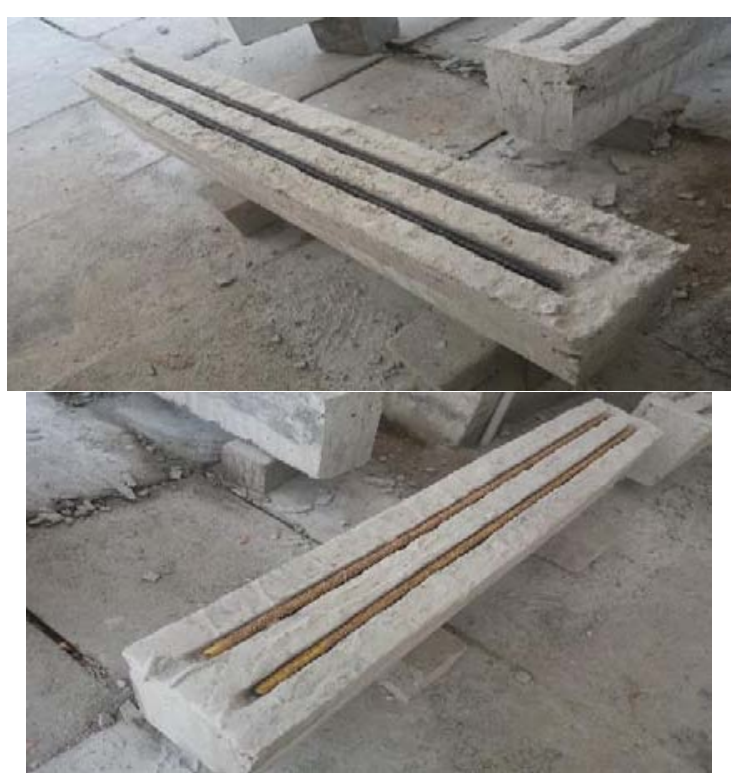

Figure 7: Strengthening by NSM method

For flexural strengthening EBR and NSM methods were used. In EBR method, GFRP sheet was glued on the concrete surface as U wrap. Details of EBR method are shown in Fig .7 and 8.

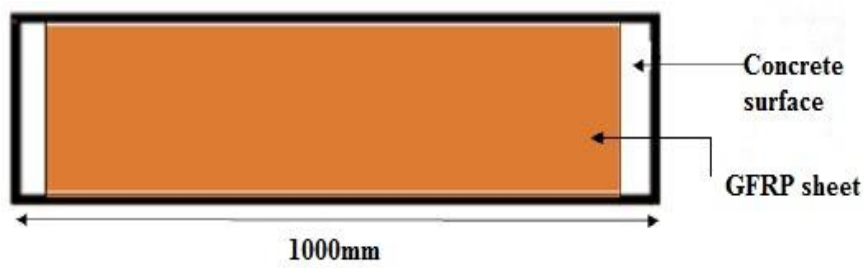

Figure 7: EBR method -Flexural strengthening

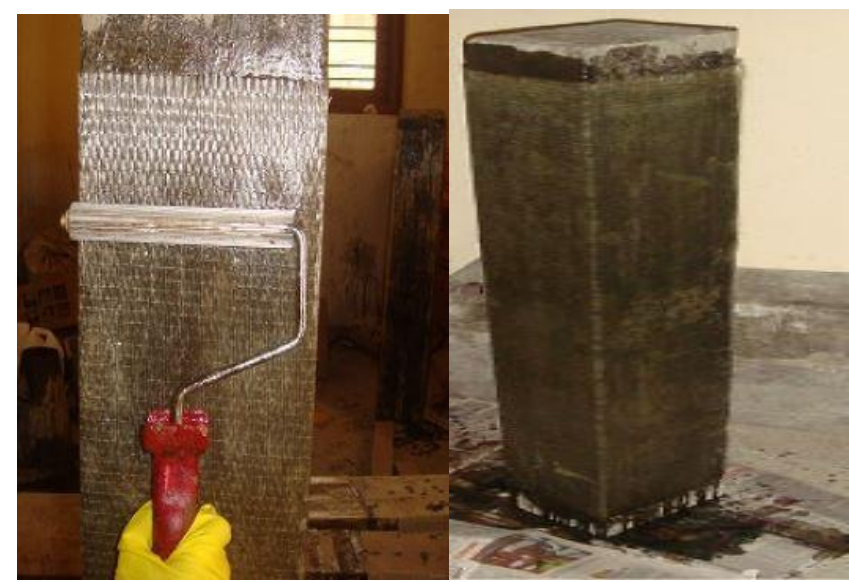

Figure 8: EBR technique

\section{Test Procedure}

The specimens are simply supported, $1 \mathrm{~m}$ long, concrete beams casted and tested under the Universal Testing Machine (UTM). A two- point loading system is adopted for this test. An LVDT was kept at the middle of the beam to find the midspandeflection. At the end of each load increment, deflection and crack width were observed. The ultimate load and maximum deflection was noted for each specimen. The test setup of a control beam specimen is shown in Fig 9.below.
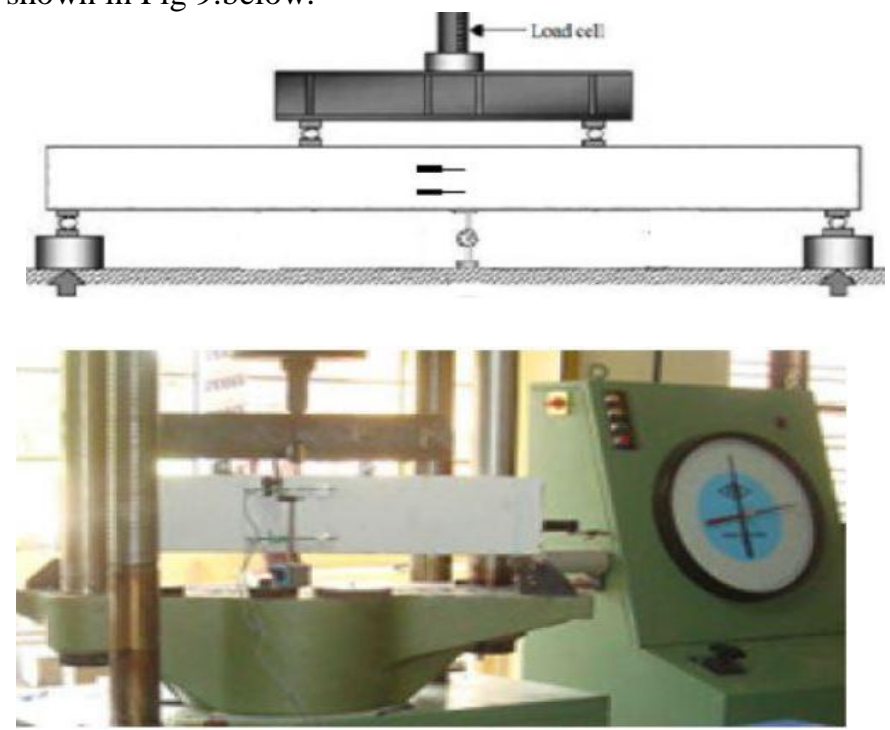

Figure 9: Load test setup

\section{Results and Discussions}

The specimens were of M20 mix designed as per IS 1026:2009 guidelines. Selected mix proportion was 1: 1.63 3.04. Total number of beam specimens used in this study is 9. For each type 3 specimens were tested after 28 days of curing. The load deflection behaviour of reinforced concrete beams are discussed here. Fig 10, 11 and Table3shows the load deflection behaviour of control specimen and the retrofitted beams with EBR and NSM method.

Table 3: Test result

\begin{tabular}{|c|c|c|c|c|}
\hline $\begin{array}{c}\text { Beam } \\
\text { Designation }\end{array}$ & $\begin{array}{c}\text { First crack } \\
\text { load }(\mathrm{kN})\end{array}$ & $\begin{array}{c}\text { Ultimate } \\
\text { load } \\
(\mathrm{kN})\end{array}$ & $\begin{array}{c}\text { Preload } \\
(\mathrm{kN})\end{array}$ & $\begin{array}{c}\text { \% Increase in } \\
\text { ultimate load }\end{array}$ \\
\hline CB & 5 & 15.5 & - & - \\
\hline FRG1 & 5 & 18.6 & 11.5 & 20 \\
\hline FRG2 & 5 & 20 & 11.5 & 29 \\
\hline FRG3 & 5 & 18.3 & 11.5 & 18 \\
\hline FRS1 & 5 & 17.2 & 11.5 & 10.96 \\
\hline FRS2 & 5 & 17.5 & 11.5 & 12.90 \\
\hline FRS3 & 5 & 17.7 & 11.5 & 14.19 \\
\hline
\end{tabular}




\section{International Journal of Science and Research (IJSR) \\ ISSN (Online): 2319-7064}

Index Copernicus Value (2013): 6.14 | Impact Factor (2015): 6.391

\subsection{Ultimate Load}

\section{LOAD vs DEFLECTION GRAPH}

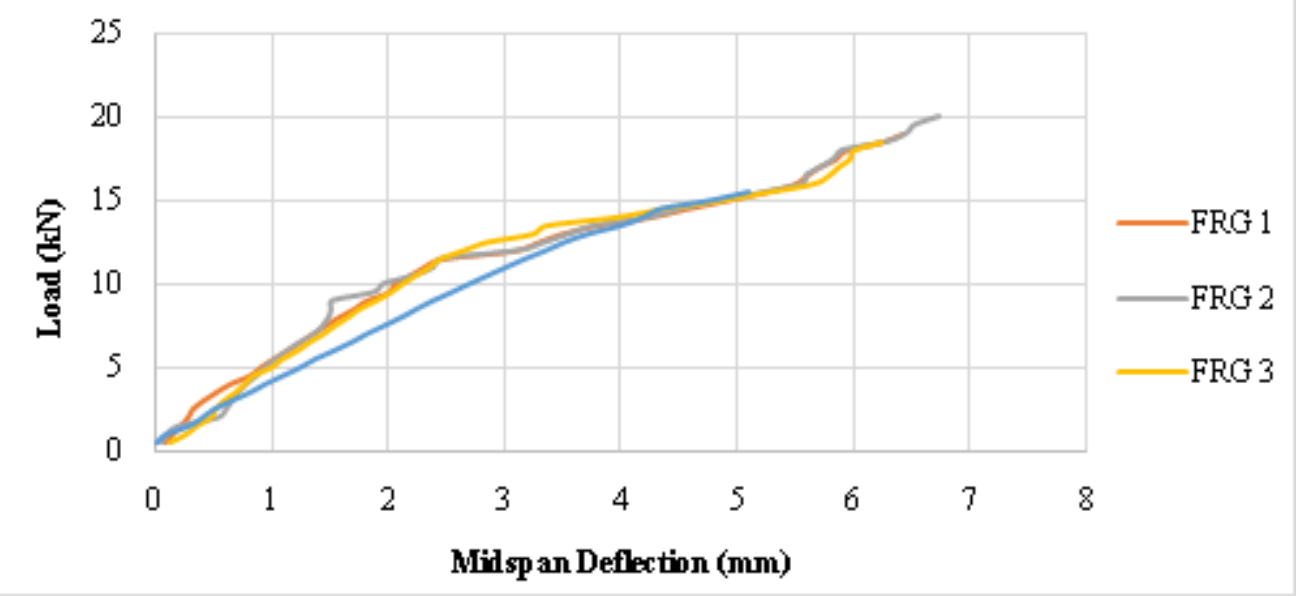

Figure 10: Midspan deflection vs load graph between control and NSM GFRP specimens

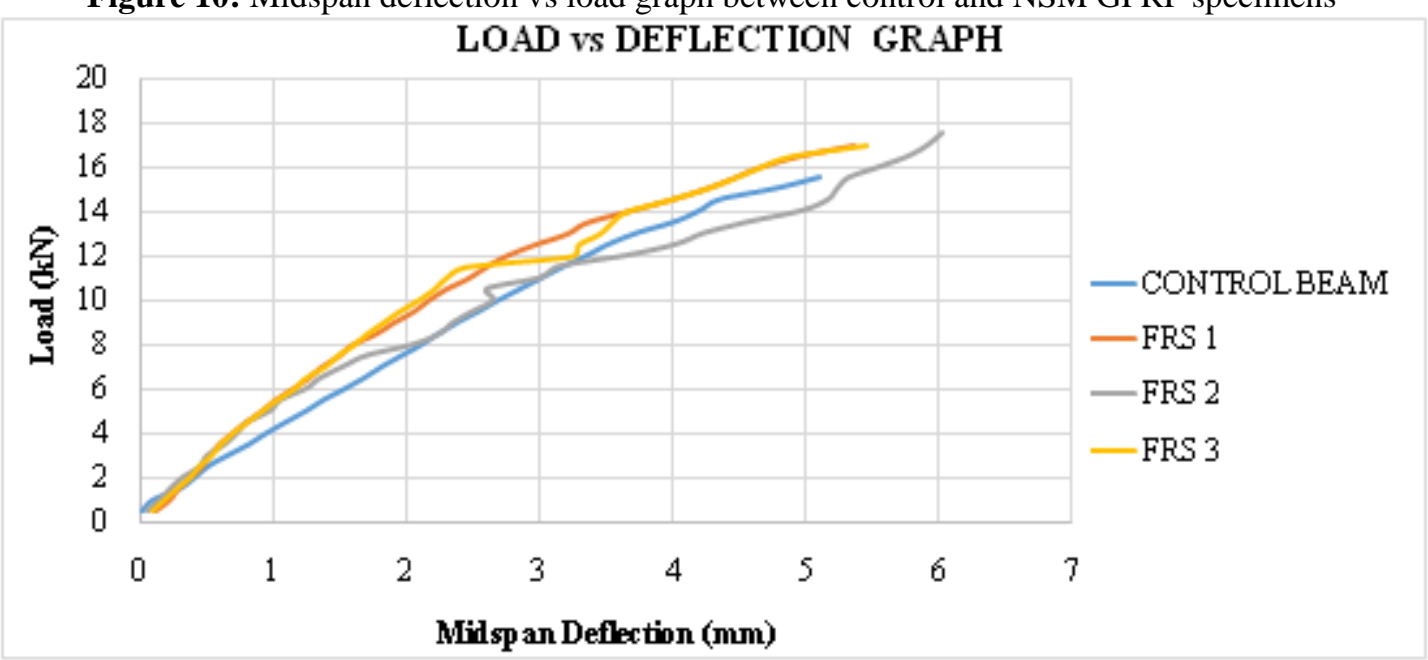

Figure 11: Midspan deflection vs load graph between control and NSM steel specimens

Compared to the conventional reinforced beams, the result shows an increase in the ultimate applied load up to $20 \%$. All beams retrofitted with NSM GFRP rods and externally with GFRP U-wraps exhibit an increase of the ultimate load of $20 \%$, and $14 \%$ for specimens retrofitted with NSM steel rods and GFRP U-wraps respectively. The retrofitted beams with NSM GFRP rods performed at the highest ultimate load $(20 \mathrm{kN})$ compared to those specimens retrofitted with NSM steel rods.

\subsection{Deflection Behaviour}

Fig10 and 11shows the load-deflection behaviour for conventional reinforced beams and retrofitted beams respectively. The result shows that all beams retrofitted with NSM bars behaved in a ductile manner. Beams were stiffer compared to plain reinforced beams. The ascending part in deflection curves of all beams was analogous to thedeflection curve of plain reinforced beams. Nevertheless, the curves of retrofitted beams lay slightly above the path of the deflection curves of the plain reinforced beams. Deflection curves ofthe retrofitted beams, however, have a continuingincreasing in line up to an elastic point higher than the elastic point of plain reinforced beams by 5.88\%, $10.4 \%$ for steel, and GFRP bars respectively, with relatively less deflection compared to control beams. This retrofitting technique has significantly enhanced the strength and increased the ultimate applied load of the preloaded beams and gave better performance than the conventional reinforced beams.

\subsection{Cracking and Failure Mode}

The failure modes of all the beams are shown in Fig 11 and 12. The cracking and crushing patterns of all beams have been shown, since beams in each category have performed similar cracking and crushing behaviour. All beams were designed to fail in flexure. Shear cracks were noticed in all beams. Some shear cracks remained open and some cracks were small and were closed after the dropping of the load to zero. Flexure and shear cracks in control beam specimens were initiated simultaneously. Only flexure cracks were propagated with the increase of applied loads until failure. The main cracks started to perform near the two point loads, the initiative cracks started to be observed diagonally from the point load toward the bottom of the beam. These cracks were between the point loads and the supports, but closer to the point loads. Then flexure cracks started to perform and propagate in-between and under the two point loads until failure. Prior to failure, crushing on top of the beam at the retrofitted material occurred. Unlike the plain reinforced beams, where shear and flexure cracks initiated 


\section{International Journal of Science and Research (IJSR) \\ ISSN (Online): 2319-7064 \\ Index Copernicus Value (2013): 6.14 | Impact Factor (2015): 6.391}

simultaneously, the retrofitted material at the bottom section strengthened the beam at the mid span, which delayed the initiation of cracks at the flexural zone until an appropriate applied load had been reached that was adequate to initiate the flexure cracks.

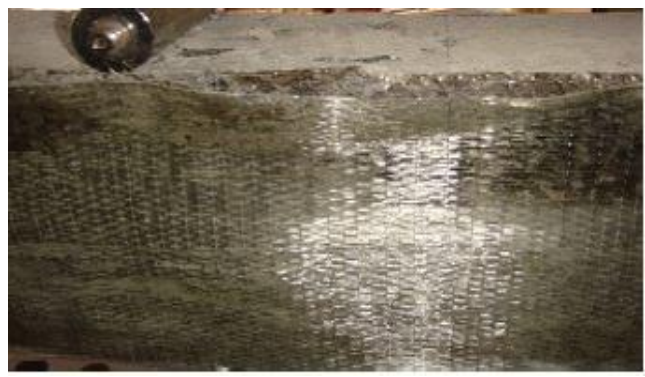

Figure 11: Debonding failure

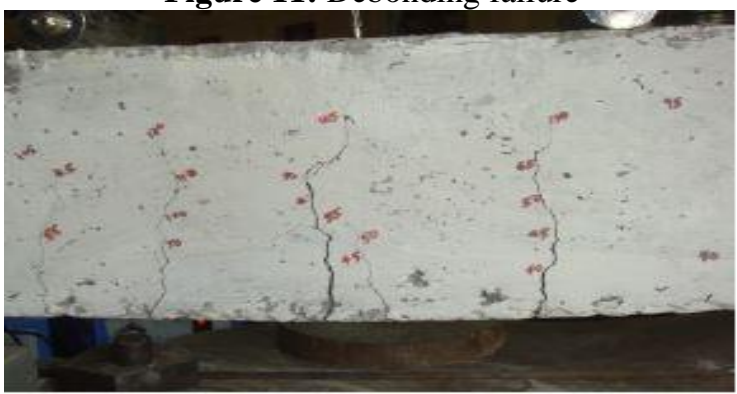

Figure 12: Flexural failure

\subsection{Energy Absorption and ductility factor}

The area under the load deflection curve indicates the energy absorption capacity. The ductility factor is calculated as the ratio of deflection at ultimate load to deflection at yield load. [5] ,[6]. The energy absorption capacity and ductility factor of various specimens are shown in Table 4. Energy absorption capacity and ductility of the strengthened beams are higher compared to control beams.

Table 4: Test result- Flexural strengthening

\begin{tabular}{|c|c|c|}
\hline Beam Designation & $\begin{array}{c}\text { Energy absorption } \\
\text { capacity }(\mathrm{kNm})\end{array}$ & $\begin{array}{c}\text { Ductility } \\
\text { factor }\end{array}$ \\
\hline CB & 0.075 & - \\
\hline FRG1 & 0.119 & 1.125 \\
\hline FRG2 & 0.136 & 1.25 \\
\hline FRG3 & 0.117 & 1.125 \\
\hline FRS1 & 0.088 & 1.142 \\
\hline FRS2 & 0106 & 1.071 \\
\hline FRS3 & 0.091 & 1.23 \\
\hline
\end{tabular}

\section{Conclusions}

From the study carried out, the following conclusions were been drawn.

- The NSM steel strengthened beams increased the ultimate load up to 29\% compared to the control beam.

- The NSM GFRP strengthened beams increased the ultimate loads up to $14 \%$ compared to the control beam.

- NSM GFRP improved greater ultimate capacity compared to NSM steel due to high tensile strength of GFRP bars.

- Beams retrofitted with NSM rods and external Uwrapping gave a significant performance on loaddeflection behaviour.
- Retrofitted beams were relatively stiffer than control beams and they produce higher elastic point than the elastic point of control beams by $13 \%$ for GFRP rods and $7 \%$ for steel rodsrespectively.

- Prior to failure, flexural cracks were propagated with the increase of load. Subsequently, beams fail in flexural.

\section{References}

[1] Robert Capozuca „On the strengthening of RC beams with near surface mounted (NSM) GFRP rods ${ }^{e e}$, Composite Structures, 2014. Published by Elsevier Ltd.

[2] N. Attaria, S Amziane, Chemrouk ,Flexural strengthening of concrete beams using CFRP, GFRP and hybrid FRP sheetse, Construction and Building Materials, 2012. Published by Elsevier Ltd.

[3] I.A. Sharaky , L. Torres , M. Baena , C. Miàs „An experimental study of different factors affecting the bond of NSM FRP bars in concrete"e, Composite Structures, 2013. Published by Elsevier Ltd.

[4] Tarek H. Almusallam, Hussein M. Elsanadedy ,1, Yousef A. Al-Salloum, Saleh H. Alsayed „Experimental and numerical investigation for the flexural strengthening of RC beams using near-surface mounted steel or GFRP barse Construction and Building Materials,2013. Published by Elsevier Ltd.

[5] I.A. Sharaky, L. Torres , H.E.M. Sallam „Experimental and analytical investigation into the flexural performance of RC beams with partially and fully bonded NSM FRP bars/strips ${ }^{\text {ee }}$ Composite Structures,2015. Published by Elsevier Ltd.

[6] Near-Surface-Mounted Fiber-Reinforced PolymerReinforcements for Flexural Strengthening of Concrete Structures by Raafat EI-Hacha and Sami H. Rizkalla, ACI Structural Journal/September-October 2004

[7] A review on the bond behavior of FRP NSM systems in concrete Mário R.F. Coelho a,^, José M. Sena-Cruz a, Luís A.C. Neves b Construction and Building Materials Construction and Building Materials

[8] Meier, U. and Winistorfer, A., "Retrofitting of structures through external bonding of CFRPsheets", Non-Metallic (FRP) Reinforcement for Concrete Structures, Proceedings of the SecondInternational RILEM Symposium, E \& FN Spon, London, UK

[9] H. Waang, A. Belarbi, "Ductility characteristics of FRC beams Reinforced with FRP bars", Composites Vol.25,2010.

[10] H. S. Kim, Y. S. Shin, "Flexural behavior of reinforced concrete (RC) beams retrofitted with hybrid fibre reinforced polymer", Composite Structures Vol.93, 2010

[11]Md. Akter Hosen, Mohd Zamin Jumaat" Flexural Strengthening of RC Beams with NSM Steel Bars", International Conference on Food, Agriculture and Biology (FAB-2014) June 11-12, 2014 Malaysia.

[12] T.Manikandan. G.Balaji Ponraj,"Strengthening of RC Beam Using GFRP Wraps", International Journal of Engineering Trends and Technology (IJETT) - Vol.4, Issue 5-2013 